\title{
The impact of direct and indirect taxes on the growth of the Turkish economy
}

SUNA KORKMAZ, Ph.D.*

METEHAN YILGOR, Ph.D.*

FADIME AKSOY, Ph.D. candidate*

Preliminary communication **

JEL: C22, E62, O47

https://doi.org/10.3326/pse.43.3.5

\footnotetext{
* The authors would like to thank to the two anonymous referees for helpful comments on the paper.

** Received: July 9, 2019

Accepted: July 31, 2019
}

Suna KORKMAZ

Bandırma Onyedi Eylul University, Department of Economics, 10200 Bandırma, Turkey

e-mail: skorkmaz@bandirma.edu.tr

ORCiD: 0000-0001-6221-2322

\section{Metehan YILGOR}

Bandırma Onyedi Eylul University, Department of Econometrics, 10200 Bandırma, Turkey e-mail: myilgor@bandirma.edu.tr

ORCiD: 0000-0001-6921-6684

\section{Fadime AKSOY}

Bandırma Onyedi Eylul University, Department of Econometrics, 10200 Bandırma, Turkey e-mail: fcelik@bandirma.edu.tr ORCiD: 0000-0003-0211-8304 


\begin{abstract}
Governments are able to implement monetary and fiscal policies to achieve economic objectives, such as increasing production, ensuring price stability, improving the balance of payments, and achieving full employment. While central banks carry out monetary policies, governments, in contrast, develop fiscal policies. Fiscal policy instruments can include public expenditures, taxes, and borrowing. In countries that have low savings levels, individuals participate in public expenditures by spending a large part of their income.
\end{abstract}

Therefore, taxes are effectively used as a major policy instrument. The impact of both direct and indirect taxes on economic growth in Turkey has been analyzed by employing the autoregressive distributed lag (ARDL) approach. Test results suggest a positive and significant impact of indirect taxes on economic growth as well as a negative and significant impact of direct taxes.

Keywords: ARDL, direct taxes, economic growth, indirect taxes, Turkey

\title{
1 INTRODUCTION
}

Governments can implement tax policies as a fiscal policy instrument to make certain expenditures and finance their investments. Tax policies to be implemented may vary depending on targeted objectives. Tax policies may help individual governments raise higher revenues with the aim of financing public expenditures, reducing the balance of payments or trade balance deficits, or encouraging growth and development by granting incentives. Taxes have always been a very popular subject of discussion in the literature on economics. Moreover, the tax rates to be levied and their reflections on the economy have always been a popular topic. Economic doctrines supporting government intervention in the economy have brought forward recommendations on the taxation policies of the state. Keynes's emphasis was on the potential for government spending and taxation to influence aggregate demand. Keynes says that changes in government spending or taxation are multiplied in their effect on the economy. The key element in this multiplier effect is how consumers respond to changes in their incomes. Keynes declared that governments should increase spending and cut taxes to boost their economies (Nelson, 2006:2). The supply-side economist Arthur Laffer stated that an increase in tax rates lowers or only causes a small increase in tax revenue because people avoid taxation, which lowers the tax base (Kazman, 2014). Supply-side economists strongly argue that tax rates should be lowered to increase economic production.

The taxation system currently in force in Turkey is a multiple tax system, taxes being classified as either direct or indirect. The distinction between direct and indirect taxes is based on whether their burden can be shifted from the initial taxpayer to others. Taxes where the burden can be shifted to others are indirect, and taxes where the burden cannot be shifted to any other person are direct. If the taxable event is of a continuous nature, then the consequent taxes are classified as direct. If the taxable event arises occasionally and is not of a continuous nature, 
then the consequent taxes are classified as indirect (Erdem, Şenyüz and Tatlıoglu, 2012:113-115). The tax bearer pays direct taxes to the government. The government directly levies taxes on people and businesses. An intermediary, on the other hand, collects indirect taxes from the person bearing the ultimate financial burden of the tax. Therefore, the taxpayer and the tax bearer are different in relation to these types of taxes. Taxes levied on revenues and wealth are classified as direct taxes, whereas taxes levied on expenditures on goods and services are classified as indirect taxes. Taxes levied on revenues comprise personal income taxes and corporate income taxes. Taxes levied on expenditures, on the other hand, comprise value-added taxes, excise duties, special communication taxes, gambling taxes, customs duties, banking and insurance taxes, stamp duties, fees levied on negotiable instruments, and other fees and charges. The largest share among these taxes is taken by value-added tax. Taxes levied on wealth comprise motor vehicle taxes, estate taxes, and property taxes.

A shift from direct to indirect taxes has advantages and disadvantages. The advantages and disadvantages of indirect taxes are given in table 1 (Özdemir, 2009: 17-18).

\section{TABLE 1}

The advantages and disadvantages of indirect taxes

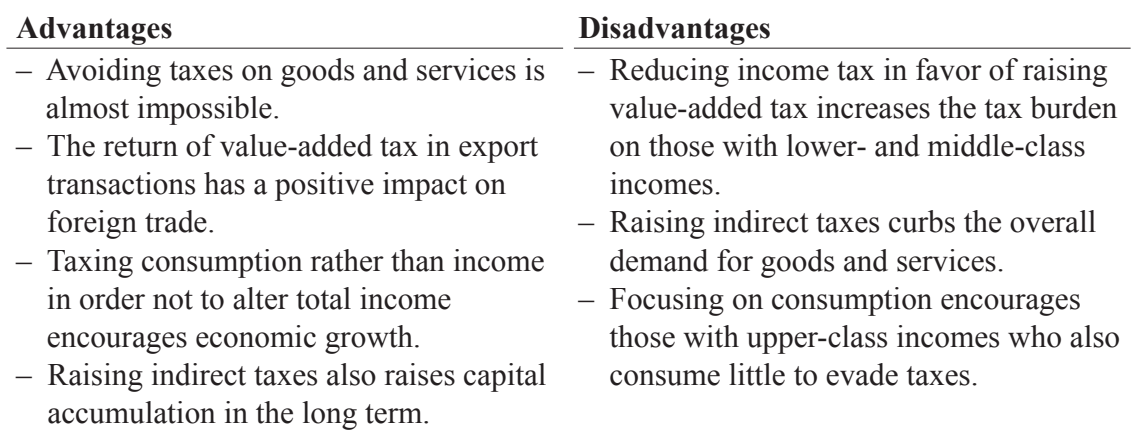

Source: Özdemir (2009:17-18).

The relationship between economic growth and tax revenues is one of the most controversial areas in the literature. Although there are many variables that shape economic growth, tax has a much more pronounced effect on economic growth with its direct and indirect effects. Tax revenues are one of the most important revenues of the Turkish economy. The amount of tax revenues has increased continuously over the years, and in 2018, the amount of tax revenues reached $24 \%$ of the Turkish national product. This has motivated the present study, which aims to investigate the relationship between tax revenues and economic growth in Turkey. This study involves an analysis of the impact of direct taxes and indirect taxes on economic growth in Turkey. The following research hypotheses are suggested.

Hypothesis 1: Direct taxes have negative effects on economic growth, affecting GDP negatively. 
Hypothesis 2: Indirect taxes have positive effects on economic growth, affecting GDP positively.

The remaining part of this study is organized as follows: section 2 overviews related studies. The data and estimation methodology employed are discussed in section 3. Section 4 describes the empirical findings, and finally we present our conclusions.

\section{LITERATURE REVIEW}

Anastassiou and Dritsaki (2005) noted a unidirectional causal relationship between total tax revenues and economic growth as a result of an analysis conducted on annual data from Greece from between 1965 and 2002. Ferede and Dahlby (2012) by using panel data covering 1977 to 2006 found that a higher provincial statutory corporate income tax rate was associated with lower private investment and slower economic growth. Stoilova and Patonov (2012) using data from 1995 to 2010 examined the major tendencies in 27 European Union member countries in the distribution of the total tax burden. The study found that direct taxes had a more efficient impact on economic growth. Muriithi (2013) found that in Kenya, an increase in value-added tax rates had a positive impact on economic growth between 1992 and 2011. Kesavarajah (2014) noted a unidirectional causal relationship from income taxes, value-added taxes, and international taxes toward economic growth as a result of an analysis conducted on Sri Lankan annual data from between 1980 and 2013.

Dehghan and Nonejad (2015) used the least squares approach to analyze annual data from Iran from between 1981 and 2010. The results of their analyses suggest a negative impact of corporate taxes, business taxes, and indirect taxes on economic growth. Iqbal, Azam and Shinwari (2015) noted a positive impact of general taxation excluding workers' wealth tax on economic growth upon examining statistical data for Pakistan between 1979 and 2010. In studying South Africa, Phiri (2016) noted that the optimal tax rate was $10.27 \%$ according to an STR analysis conducted using time series data collected from 1990:Q1 to 2015:Q2. Indirect taxes were positively related to economic growth, while direct taxes adversely affected growth below this threshold. Etale and Bingilar (2016) noted that company income tax and value-added tax had a significant positive impact on economic growth in Nigeria for the period 2005-2014. Ahmad, Sial and Ahmad (2016) applied the ARDL approach to annual data for the period 1974-2010 in Pakistan. The results of the research study suggest that indirect taxes should be reduced and direct taxes should be incremented to increase economic growth.

Babatunde, Ibukun and Oyeyemi (2017) proved that tax revenues had a significant positive influence on economic growth throughout Africa between 2004 and 2013. In examining Croatia from 2000 to 2016, Palić, Žmuk and Grofelnik (2017) noted that personal income taxation had a significant negative impact on economic growth. Geetanjali and Venugopal (2017) used the OLS approach for the period 
2000-2016 for India. The researchers concluded that there is a significant impact of direct taxes on economic growth. Kalaš, Mirović and Andrašić (2017) studied American data from 1996 to 2016 and demonstrated that an increase in tax revenues and social security contributions had a significant effect on economic growth, while personal income tax and corporate income tax did not have a significant impact. Nonvide and Amegnaglo (2017) used the OLS approach to reveal that tax revenues had a positive effect on Benin's economic growth. Egbunike, Emudainohwo and Gunardi (2018) examined the economies of Nigeria and Ghana between 2000 and 2016 and showed that tax revenues had a positive effect on economic growth. Using an error correction model for data from 1980 to 2015, Mdanat et al. (2018) demonstrated that consumption and tariffs had a positive effect on per capita gross domestic product (GDP) growth, whereas income taxes negatively influenced this growth measure in Jordan.

\section{DATA AND METHODOLOGY}

This study investigates the effect of indirect and direct taxes on economic growth in Turkey using the ARDL model. To calculate this relationship, quarterly data series for the period 2006:Q1-2018:Q3 were used. Since the $4^{\text {th }}$ quarter 2018 data have not yet been published, we were unable to use them. All the data used in this study were collected from the Central Bank of the Republic of Turkey (EVDS, 2019). The GDP variable was seasonally adjusted and estimated based on the expenditure approach. All these variables were converted into a natural logarithm for consistent and reliable empirical results (Shahbaz et al., 2016). For empirical estimation, the model was established as follows:

$$
L G D P_{t}=\alpha_{0}+\alpha_{1} L I T_{t}+\alpha_{2} L D T_{t}+\varepsilon_{t}
$$

In this equation, GDP, referred to as economic growth, is the dependent variable of the model, LIT is indirect taxes, LDT is direct taxes, $\alpha_{0}$ is the constant term, $\alpha_{1}$ , $\alpha_{2}$ is the cointegrating vector to be estimated, and $\varepsilon_{t}$ is the classical error term. All variables are expressed in thousand TL. The data description for the model is depicted in table 2, where mean, median, minimum, maximum, standard deviation, skewness, kurtosis, and Jarque-Bera test values show their properties. The skewness and kurtosis values portrayed in table 2 suggest that the dataset does not have any skewed value problems or complications. The Jarque-Bera value is insignificant, which proves that all the variables are normally distributed.

It is imperative to check the stationary conditions of the variables prior to performing a time series analysis to avoid the spurious regression problem (Newbold and Granger, 1974). Hence, we examined the stationary condition of all variables using the augmented Dickey-Fuller (ADF, 1979) and Phillips-Perron (PP, 1988) tests. 
TABLE 2

Descriptive statistics

\begin{tabular}{|c|c|c|c|}
\hline $\begin{array}{l}\text { Descriptive } \\
\text { statistics }\end{array}$ & LGDP & LIT & LDT \\
\hline Mean & 19.5805 & 16.5633 & 15.4622 \\
\hline Median & 19.5677 & 16.5482 & 15.4209 \\
\hline Maximum & 19.9026 & 17.3774 & 16.5224 \\
\hline Minimum & 19.2969 & 15.8865 & 14.5990 \\
\hline Standard deviation & 0.2010 & 0.4677 & 0.4942 \\
\hline Skewness & 0.1154 & 0.0344 & 0.1649 \\
\hline Kurtosis & 1.5702 & 1.7247 & 1.9648 \\
\hline Jarque-Bera & 4.5444* & $1.7247 *$ & $2.5577^{*}$ \\
\hline
\end{tabular}

Note: ${ }^{*}$ indicates a significance level of $5 \%$.

According to the econometric methodology, based on stationarity criteria, the long-term association between two or more variables is calculated through the ARDL approach, The ARDL bound-testing approach, as recommended by Pesaran and Shin (1999) and Peseran et al. (2001), was used to establish the long- and short-term dynamics between indirect and direct taxes and economic growth. The ARDL bound-testing approach was preferred over other econometric techniques (e.g. those of Engle and Granger, 1987; and Johansen and Juselius, 1990) because it permits variables to be stationary at different degrees $[\mathrm{I}(0), \mathrm{I}(1)]$ and regressors to have different optimal lag lengths according to the traditional cointegration procedure (Pesaran, Shin and Smith, 2001; Giles, 2013).

\section{FINDINGS}

To determine the stationarity of the data, we applied ADF and PP unit root tests, and the results of both tests are presented in table 3 . As a few variables were $I(0)$ and the remaining were $I(1)$, the results directed us to opt for the ARDL bound test (Pesaran et al., 2001). The results of both tests revealed that the GDP variable was difference stationary, whereas the variables and indirect and direct taxes were trend stationary.

\section{TABLE 3}

Unit root test results

\begin{tabular}{|c|c|c|}
\hline Variable & ADF & PP \\
\hline LGDP & $-2.032(-4.148)$ & $-1.444(-4.152)$ \\
\hline$\Delta$ LGDP & $-6.963(-4.152)^{*}$ & $-7.504(-4.156) *$ \\
\hline LIT & $-4.349(-4.148)^{*}$ & $-4.245(-4.148)^{*}$ \\
\hline LDT & $-5.790(-4.152)^{*}$ & $-5.996(-4.148)^{*}$ \\
\hline
\end{tabular}

Note: "indicates a significance level of $1 \%$. Figures in parentheses are critical values of test statistics. Schwarz information criterion is used.

The change in economic growth was modeled as a function of the lag of variables and indirect and direct taxes. This is an unrestricted error correction model with a deterministic trend, whereby the $\phi, \delta$, and $\Upsilon$ coefficients represent the short-term 
relationship and the $\alpha$ coefficient represents the long-term relationship. The unrestricted error correction model was established as follows:

$$
\begin{aligned}
L G D P= & \alpha_{0}+\alpha_{1} L G D P_{t-1}+\alpha_{2} L I T_{t-1}+\alpha_{3} L D T_{t-1}+\sum_{i}^{p} \Upsilon_{i} \Delta \mathrm{LGDP}_{t-i} \\
& +\sum_{j}^{q} \delta_{j} \Delta \mathrm{LIT}_{t-j}+\sum_{m}^{r} \phi_{m} \Delta \mathrm{LDT}_{t-m}+\beta \text { trend }+\varepsilon_{t}
\end{aligned}
$$

The hypotheses used to test the existence of cointegration between the variables in the model are as follows:

$$
\begin{gathered}
H_{0}: \alpha_{0}=\alpha_{1}=\alpha_{2}=\alpha_{3}=0 \text { (There is no cointegration in these series) } \\
H_{1}: \alpha_{0} \neq \alpha_{1} \neq \alpha_{2} \neq \alpha_{3} \neq 0 \text { (There is cointegration in these series) }
\end{gathered}
$$

Each hypothesis was tested using an F test. The optimal lag length of the model was calculated as $(4,1,0)$ by considering the AIC information criterion, as shown in table 4. The F-statistics value (14.16) calculated at the $1 \%$ significance level was higher than the upper-bound critical value (8.72) at the $5 \%$ level of significance. This indicates the existence of a cointegration relationship between Tur-

\begin{tabular}{|c|c|c|c|c|}
\hline Estimated model & Optimal lag & F-statistics & Lower bound & $\begin{array}{l}\text { Upper bound } \\
\text { cointegration }\end{array}$ \\
\hline & & & 4.38 & $5.35(10 \%)$ \\
\hline LGDP $=f($ LIT, LDT $)$ & $(4,1,0)$ & 14.16 & 5.24 & $6.30(5 \%)$ \\
\hline \multicolumn{5}{|l|}{ Exists } \\
\hline & & & 7.33 & $8.72(1 \%)$ \\
\hline
\end{tabular}
key's indirect and direct taxes and its economic growth.

\section{TABLE 4}

ARDL bound-testing cointegration results

The results of the long-term estimation found under the ARDL model framework are presented in table 5 . The test results indicate that a $1 \%$ increase in direct taxes leads to an $8 \%$ decrease in economic growth. Similarly, a $1 \%$ increase in indirect taxes leads to a $27 \%$ increment in economic growth (shown in table 5 in bold). The

\begin{tabular}{|c|c|c|c|}
\hline Variables & Coefficients & t-statistics & p-value \\
\hline LGDP_SA(-1) & 0.4419 & 3.1087 & 0.0035 \\
\hline LGDP_SA(-2) & -0.0530 & -0.3567 & 0.7232 \\
\hline LGDP_SA(-3) & 0.0872 & 0.5906 & 0.5582 \\
\hline LGDP SA(-4) & 0.3035 & 2.2880 & 0.0276 \\
\hline LIT_SA & 0.2795 & 6.1999 & 0.0000 \\
\hline LIT_SA(-1) & 0.1166 & 2.4336 & 0.0196 \\
\hline LDT_SA & -0.0892 & -3.3311 & 0.0019 \\
\hline $\mathrm{C}$ & -0.6772 & -0.4504 & 0.6549 \\
\hline @TREND & -0.0064 & -3.2102 & 0.0027 \\
\hline
\end{tabular}
fixed variate is statistically insignificant, whereas the trend variable is significant.

\section{TABLE 5}

ARDL long-term estimation results 
Table 6 lists the results of the estimation found by using error correction. The CointEq (-1) coefficient is the long-term equilibrium speed of adjustment. This coefficient is significant and negative at the $1 \%$ level. This means that $22 \%$ of any disequilibrium occurring in the previous quarter is corrected in the next one. The variables, indirect taxes, and direct taxes are statistically significant. This means that the variables, indirect taxes, and direct taxes have, in the short term, an impact on the GDP. The coefficient of short-term indirect taxes indicates that an increase in indirect taxes has a positive impact on economic growth. Direct taxes, on the other hand, have a negative impact on economic growth.

TABLE 6

ARDL error correction approach estimates (short-term estimation)

\begin{tabular}{|c|c|c|c|}
\hline Variables & Coefficients & t-statistics & p-value \\
\hline LIT_SA & 1.7983 & 2.9701 & 0.0051 \\
\hline LDT_SA & -0.4052 & -2.1865 & 0.0348 \\
\hline CointEq(-1)* & -0.2203 & -6.6839 & 0.0000 \\
\hline
\end{tabular}

We also checked serial correlation using the Breusch-Godfrey serial correlation LM test and heteroskedasticity using the White test. The diagnostic test results of the model are presented in table 7. The Breusch-Godfrey LM test indicated no autocorrelation in the model. The results of the White test, which is used to detect the presence of heteroskedasticity, indicated no heteroskedasticity.

\section{TABLE 7}

Diagnostic test results

\begin{tabular}{|c|c|c|}
\hline Test & F-statistics & p-value \\
\hline Breusch-Godfrey LM test & 0.2147 & 0.8077 \\
\hline White test & 0.581 & 0.4796 \\
\hline
\end{tabular}

Furthermore, we also found the model to be stable as shown in figure 1. The stability of the regression coefficients was evaluated using the cumulative sum (CUSUM) and the cumulative sum of squares (CUSUMSQ) of the recursive residual test for structural stability (Brown, Durbin and Evans, 1975). The regression equation appears stable, given that neither the CUSUM nor the CUSUMSQ test statistics exceed the bounds of the $5 \%$ level of significance.

Plots of each test (figure 1) were generated based on the ARDL estimates of our model. The values of residuals are shown in straight lines and their confidence levels are shown in dashed lines on the graph. All residual values are within confidence lines, thus suggesting the consistency of our ARDL model. 
Figure 1

Plots of cumulative sum (CUSUM) and cumulative sum of squares (CUSUMSQ)
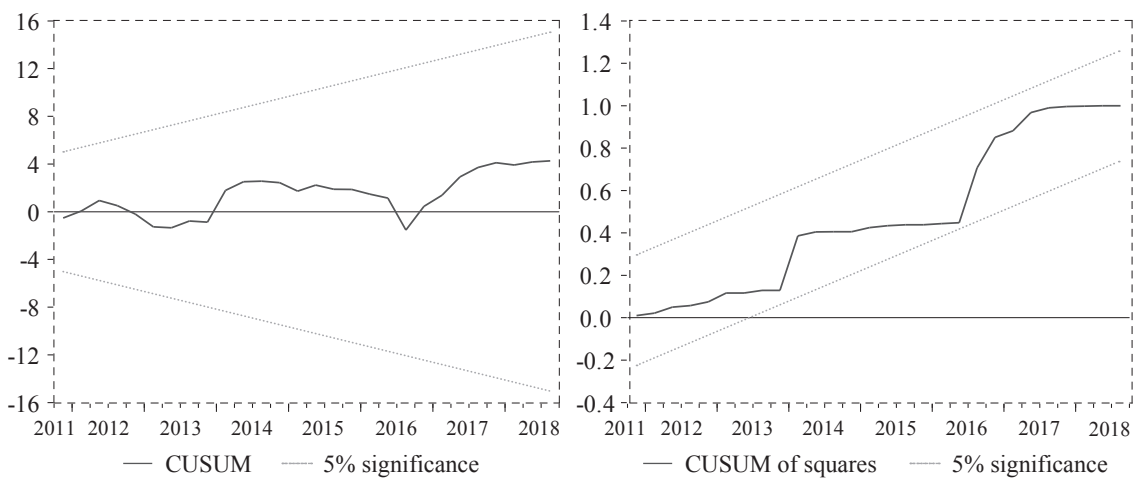

\section{CONCLUSIONS}

Governments collect taxes to fulfill certain public services; tax revenues are used to finance education and health care expenditures as well as public investments. Developing countries use taxes for various purposes. They likewise create taxation policies which are developed to regulate the allocation of resources, support private sector investments through incentives, control inflation, palliate inequality between income and wealth, and create resources for the public sector. Any increase or decrease in the tax rates will significantly affect economic indicators. In Turkey, taxes are either direct or indirect. An increase in direct tax rates will reduce disposable personal income, therefore lowering the overall demand for goods and services which in turn adversely affects economic growth. A decrease in the overall demand for goods and services will consequently reduce indirect tax revenues. The resulting reduction in the level of overall expenditures on goods and services will thus lead to a decrease in value-added tax revenues, which ultimately comprises the largest portion of indirect taxes. Although an increase in tax rates will slow economic growth, it might contribute positively to the solution to another economic problem. An increase in tax rates would reduce the overall demand for goods and services, and result in a decrease in demand-pull inflation in countries struggling with inflation.

This study was motivated by the need for an empirical analysis of the impact of tax rises on the growth of tax revenues which is an important resource for Turkey's economy. In this study we have used the bounds testing approach to cointegration (developed within an autoregressive distributed lag framework) to investigate whether there is a long-run equilibrium relationship between economic growth, direct taxes, and indirect taxes for the period 2006:Q1-2018:Q3. The results of the findings of this study ultimately suggest there is a positive and significant impact of indirect taxes on economic growth, and a negative and significant impact of direct taxes both in the short run and the long run. CUSUM and CUSUMQ tests indicate that the model is structurally stable. Personal and 
corporate income taxes collected from Turkish taxpayers affect economic growth adversely, given that they reduce individuals' disposable personal income. However, value-added taxes and excise duties, both of which count as indirect taxes, affect economic growth positively by increasing the revenues of the state.

Our findings are strikingly different to others published in the literature, as in studies by Stoilova and Patonov (2012), Dehghan and Nonejad (2015), and Ahmad, Sial and Ahmad (2016). Our findings are similar to those of studies conducted by Muriithi (2013), Phiri (2016), Palić, Žmuk and Grofelnik (2017), and Mdanat et al. (2018). The number of indirect taxes implemented in Turkey dramatically outweighs the number of direct taxes that are implemented; this seems to support our findings. In other words, indirect taxes have a positive impact on growth. Accordingly, we can conclude that growth occurs largely through public investments. In contrast, we found that, over the long run, there was a negative relationship between direct taxes and growth. Corporate and income taxes, which can be classed as direct taxes, have a negative impact in that they allow firms and individuals alike to save money and, consequently, also have a negative impact on private investments. Furthermore, we believe that shifting the composition of tax revenues from direct to indirect tax items will in turn significantly decrease the negative impact that direct taxes have on growth.

Our study is limited in terms of the size of the data set. Due to a lack of data at our disposal, we opted to use the period between 2006:Q1 and 2018:Q3.

What we in turn recommend is for the tax burden to be included as a variable in any future study looking at the impact of tax revenues on economic growth. This is important because sharing the tax burden in a fair and balanced manner requires one to first compare and contrast what share of taxes are direct versus indirect. Given that the ratio of direct to indirect taxes in Turkey is extraordinarily high, the amount of money that individuals and firms can save is reduced. This in turn puts a strain on the demand for goods and services. The only solution therefore is for the government to lower tax rates. We are of the opinion that not only will reducing indirect and direct tax rates contribute to the achievement of tax equity, it will also have a parallel positive impact on economic growth.

\section{Disclosure statement}

No potential conflict of interest was reported by the authors. 


\section{REFERENCES}

1. Ahmad, S., Sial M. H. and Ahmad, N., 2016. Taxes and Economic Growth: An Empirical Analysis of Pakistan. European Journal of Business and Social Sciences, 5(2), pp. 16-29. https://doi.org/10.21859/eulawrev-08062

2. Anastassiou, T. and Dritsaki C., 2005. Tax Revenues and Economic Growth: An Empirical Investigation for Greece Using Causality Analysis. Journal of Social Sciences, 1(2), pp. 99-104. https://doi.org/10.3844/jssp.2005.99.104

3. Babatunde, O. A., Ibukun, A. O. and Oyeyemi, O. G., 2017. Taxation Revenue and Economic Growth in Afrika. Journal of Accounting and Taxation, 9(2), pp. 11-22. https://doi.org/10.5897/JAT2016.0236

4. Brown, R. L., Durbin, J. and Evans, J. M., 1975. Techniques for Testing the Constancy of Regression Relationships Over Time. Journal of the Royal Statistical Society: Series B (Methodological), 37(2), pp. 149-163. https://doi. org/10.1111/j.2517-6161.1975.tb01532.x

5. Dehghan, M. and Nonejad, M., 2015. The Impact of Tax Rates on Economic Growth of Iran in the Years 1981-2010. Journal of Finance and Accounting, 3(6), pp. 220-226. https://doi.org/10.11648/j.jfa.20150306.18

6. Dickey, D. A. and Fuller W. A., 1979. Distribution of the Estimators for Autoregressive Time Series with a Unit Root. Journal of the American Statistical Association, 74(366), pp. 427-431. https://doi.org/10.1080/01621459.19 79.10482531

7. Egbunike, F. C., Emudainohwo, O. B. and Gunardi A., 2018. Tax Revenue and Economic Growth: A Study of Nigeria and Ghana. Jurnal Ilmu Ekonomi, 7(2), pp. 213-220. https://doi.org/10.15408/sjie.v7i2.7341

8. Engle, R. F. and Granger, C. W., 1987. Co-Integration and Error Correction: Representation, Estimation, and Testing. Econometrica, 55(2), pp. 251-276. https://doi.org/10.2307/1913236

9. Erdem, M., Şenyüz, D. and Tatlığlu, İ., 2012. Kamu Maliyesi, 10. Bask1, Bursa: Ekin Yayınevi.

10. Etale, L. M. and Bingilar, P. F., 2016. The Impact of Company Income Tax and Value-Added Tax on Economic Growth: Evidence from Nigeria. European Journal of Accounting, Auditing and Finance Research, 4(7), pp. 106-112.

11. Ferede, E. and Dahlby, B., 2012. The Impact of Tax Cuts on Economic Growth: Evidence from the Canadian Provinces. National Tax Journal, 65(3), pp. 563-594. https://doi.org/10.17310/ntj.2012.3.03

12. Geetanjali, J V R and Venugopal, P. R., 2017. Impact of Direct Taxes on GDP: A Study. IOSR Journal of Business and Management (IOSR-JBM), pp. 21-27.

13. Giles, D., 2013. ARDL Models-Part II-Bounds Tests.

14. TCMB, 2019. Elektronik Veri Dağıtım Sistemi.

15. Iqbal, N., Azam, M. F. and Shinwari, S., 2015. Empirical Analysis of Tax Revenues and Its Impact on Economic Growth of Pakistan. Journal of Economics and Sustainable Development, 6(1), pp. 110-117. 
16. Johansen, S. and Juselius, K., 1990. Maximum Likelihood Estimation and Inference on Cointegration-With Applications to the Demand for Money. Oxford Bulletin of Economics and Statistics, 52(2), pp. 169-210. https://doi. org/10.1111/j.1468-0084.1990.mp52002003.x

17. Kalaš, B., Mirović, V. and Andrašić, J., 2017. Estimating the Impact of Taxes on the Economic Growth in the United States. Economic Themes, 55(4), pp. 481-499. https://doi.org/10.1515/ethemes-2017-0027

18. Kazman, S. B., 2014. Exploring the Laffer Curve: Behavioral Responses to Taxation. Undergraduate thesis.

19. Kesavarajah, M., 2014. Tax Composition and Output Growth: Evidence from Sri Lanka. Staff Studies Central Bank of Sri Lanka, 44(1\&2), pp. 33-67. https://doi.org/10.4038/ss.v44i1-2.4693

20. Mdanat, M. F. [et al.], 2018. Tax Structure and Economic Growth in Jordan, 1980-2015. EuroMed Journal of Business, 13(1), pp. 102-127. https://doi. org/10.1108/EMJB-11-2016-0030

21. Muriithi, C., 2013. The Relationship between Government Revenue and Economic Growth in Kenya. International Academic Journal of Information Sciences and Project Management, 1(1), pp. 87-109.

22. Nelson, C. R., 2006. Keynesian Fiscal Policy and the Multipliers. In: Macroeconomics: An Introduction, pp. 1-17.

23. Newbold, P. and Granger, C. W. J., 1974. Spurious Regressions in Econometrics. Journal of Econometrics, 2(2), pp. 111-120. https://doi.org/10.1016/03044076(74)90034-7

24. Nonvide, G. M. A. and Amegnaglo, C. J., 2017. Effect of Tax Revenues on Economic Growth in Benin: The Role of Investment. Journal of Advanced Studies in Finance, 8(2), pp. 139-145.

25. Özdemir, B., 2009. Vergi Sistemlerinde Dolaysız Vergilerden Dolaylı Vergilere Kayış ya da Tüketim Vergilerinin Artan Ağırlığı. Maliye Dergisi, 157, pp. $1-32$.

26. Palić, I., Žmuk, B. and Grofelnik, B., 2017. The Long-Run Impact of Personal Income Taxation on Economic Development: Evidence from Croatia. Croatian Review of Economic, Business and Social Statistics, 3(1), pp. 35-44. https://doi.org/10.1515/crebss-2017-0003

27. Pesaran, M. H. and Shin, Y., 1998. An Autoregressive Distributed-Lag Modelling Approach to Cointegration Analysis. Econometric Society Monographs, 31, pp. 371-413. https://doi.org/10.1017/CCOL0521633230.011

28. Pesaran, M. H., Shin, Y. and Smith, R. J., 2001. Bounds Testing Approaches to the Analysis of Level Relationships. Journal of Applied Econometrics, 16(3), pp. 289-326. https://doi.org/10.1002/jae.616

29. Phillips, P. C. B. and Perron, P., 1988. Testing for a Unit Root in Time Series Regression. Biometrika, 75(2), pp. 335-346. https://doi.org/10.1093/biomet/ 75.2 .335 
30. Phiri, A., 2016. The Growth Trade-off between Direct and Indirect Taxes in South Africa: Evidence from a STR Model. Managing Global Transitions, 14(3), pp. 233-250.

31. Shahbaz, M. [et al.], 2016. How Urbanization Affects $\mathrm{CO}_{2}$ Emissions in Malaysia? The Application of STIRPAT model. Renewable and Sustainable Energy Reviews, 57, pp. 83-93. https://doi.org/10.1016/j.rser.2015.12.096

32. Stoilova, D. and Patonov, N., 2013. An Empirical Evidence for the Impact of Taxation on Economy Growth in the European Union. Tourism \& Management Studies, 3, pp. 1031-1039. 